\title{
DECREASED OVULATION IN THE ISOLATED, PMSG-TREATED, IMMATURE RAT AND LACK OF EFFECT OF CROWDING
}

\author{
GENE B. FULLER*, M. X. ZARROW ANd V. H. DENENBERG \\ Departments of Biological Sciences and Psychology, \\ Purdue University, Lafayette, Indiana
}

(Received 9th February 1968)

\begin{abstract}
Summary. Social isolation of immature female rats produced an inhibitory effect on PMSG-induced ovulation. No effect on ovulation was observed following grouping of animals in numbers from six to twenty-four.
\end{abstract}

Although a great deal of attention has been paid to the influence of overcrowding on reproduction (Calhoun, 1962; Christian, Lloyd \& Davis, 1965), little attention has been directed to the effect of isolation. The present study is an attempt to examine the effect of both isolation and crowding on PMSGinduced ovulation in the immature rat. Previous studies from this and other laboratories have indicated that the endogenous release of $\mathrm{LH}$ in the immature rat following treatment with PMSG can be influenced by a wide variety of factors (Wilson, Runner \& Zarrow, 1963; Zarrow \& Quinn, 1963; Zarrow \& Brown-Grant, 1964; O'Steen, 1964; Hopkins \& Pincus, 1965; Zarrow \& Hurlbut, 1967) and it therefore seemed feasible to examine the effect of isolation and crowding upon this system.

Immature female rats of the Purdue-Wistar strain were used in this investigation. All litters were reduced to six at birth and weaned at 21 days of age. At this time animals were placed in suspended cages approximately $16 \times 9 \times 7 \mathrm{in}$., either singly or in groups of six, twelve or twenty-four. The PMSG was dissolved in saline at a concentration of 30 i.u. $/ 0.1 \mathrm{ml}$. All rats were killed $72 \mathrm{hr}$ after the subcutaneous PMSG injection, i.e. 10.00 hours of the 3rd day, and the ova were counted following the procedure of Zarrow, Caldwell, Hafez \& Pincus (1958). The ovaries and uteri were weighed to the nearest $0.2 \mathrm{mg}$ on a torsion balance.

All animals were maintained in a light regulated, temperature-humidity controlled environment. The light-dark cycle consisted of $13 \mathrm{hr}$ light (starting at 07.00 hours) and $11 \mathrm{hr}$ dark. Temperature was maintained between $70^{\circ}$ and $72^{\circ} \mathrm{F}$ and the relative humidity at $55 \%$. Unrestricted supplies of pellets of laboratory chow and water were available.

Analysis of variance was utilized to determine significance among the various treatment groups. Two sets of experiments were run. In the first experiment,

* Present address: Department of Animal Science, Cornell University, Ithaca, N.Y. 
treatment with PMSG was started when the rats were 24 days of age and in the second experiment when the rats were 28 days of age. Animals whose body weight when killed fell outside the limits of 55 to $75 \mathrm{~g}$ in the 24-day treatment group and 75 to $95 \mathrm{~g}$ in the 28-day treatment group were excluded from the data.

A significant decrease in the number of ova released occurred in both the 24-day $(P<0.01)$ and the 28-day $(P<0.05)$ rats maintained alone from Day 21 of age (Table 1). The ovulatory response to PMSG of animals kept in groups of six, twelve or twenty-four per cage was not significantly altered by crowding.

\section{TABLE 1}

EFFEGT OF ISOLATION AND GROWDING ON PMSG INDUCED OVULATION IN THE IMMATURE RAT

\begin{tabular}{|c|c|c|c|c|}
\hline $\begin{array}{c}\text { No. } \\
\text { rats/cage }\end{array}$ & $\begin{array}{c}\text { No. of } \\
\text { rats tested }\end{array}$ & $\begin{array}{l}\text { Final body } \\
\text { weight }(g)\end{array}$ & $\begin{array}{c}\text { Average No. } \\
\text { ova/rat } \pm \text { S.E. }\end{array}$ & $\begin{array}{c}\text { Percent. rats } \\
\text { ovulating }\end{array}$ \\
\hline $\begin{array}{c}\text { 24-day-old rats } \\
1 \\
6 \\
12 \\
24\end{array}$ & $\begin{array}{l}15 \\
11 \\
19 \\
19\end{array}$ & $\begin{array}{l}66 \cdot 1 \\
70 \cdot 2 \\
65 \cdot 0 \\
67 \cdot 6\end{array}$ & $\begin{array}{l}28.9 \pm 8.3 * \\
56 \cdot 6 \pm 11.0 \\
59.6 \pm 7.3 \\
53.1 \pm 10 \cdot 4\end{array}$ & $\begin{array}{l}66 \cdot 6 \\
81 \cdot 8 \\
89 \cdot 5 \\
73 \cdot 7\end{array}$ \\
\hline $\begin{array}{c}\text { 28-day-old rats } \\
1 \\
6 \\
12 \\
24\end{array}$ & $\begin{array}{l}20 \\
18 \\
10 \\
17\end{array}$ & $\begin{array}{l}84 \cdot 6 \\
83 \cdot 6 \\
83 \cdot 9 \\
82 \cdot 8\end{array}$ & $\begin{array}{l}42 \cdot 2 \pm 7 \cdot 6 \dagger \\
60.4 \pm 3 \cdot 0 \\
57 \cdot 8 \pm 9 \cdot 3 \\
58.5 \pm 6.8\end{array}$ & $\begin{array}{r}75 \cdot 0 \\
100 \cdot 0 \\
90 \cdot 0 \\
88.2\end{array}$ \\
\hline
\end{tabular}

* Significantly different $(P<0.01)$ from the groups containing six, twelve and twenty-four rats per cage.

$\dagger$ Significantly different $(P<0.05)$ from the groups containing six, twelve and twenty-four rats per cage.

The average ova count of these rats ranged from 53.1 to 59.6 for 24-day-old rats and from 57.8 to 60.4 for the 28-day-old rats. In the case of the isolated rats the average ova count fell to 28.9 for the 24 -day-old rats and 42.2 for the 28 -dayold rats.

The percentage of rats ovulating for the various groups tended to confirm the results obtained with the ova counts. The weights of ovaries and uteri exhibited no significantly consistent response and are not included.

Social isolation produced a significant decrease in the number of ova shed following injections of PMSG to 24-day-old and 28-day-old rats. Increasing the number of rats from six to twenty-four per cage at weaning had no effect upon the number of ova released. These results were unexpected as previous work in mice (Christian, 1955; Christian \& LeMunyan, 1958; Helmreich, 1960; Mody \& Christian, 1961) has shown reproductive function to be adversely affected by increasing population density. The earlier workers, however, segregated their animals for greater periods of time before assignment to various treatment groups than was used here. In addition the current study is restricted to an early aspect of reproduction, i.e. follicle growth, LH release and ovulation. Hence the crowding effect on FsH release, implantation and pregnancy maintenance would not be seen in this experiment. 
The work was supported by a grant, HD-02068, from the NIH, USPHS. The PMSG was obtained through the courtesy of Dr J. B. Jewell, Ayerst Laboratories, N.Y.

\section{REFERENCES}

Calmoun, J. B. (1962) The ecology and sociology of the Norway rat. Public Health Service Publication No. 1008, U.S. Government Printing Office, Washington.

Christian, J. J. (1955) Effect of population size on the weights of the reproductive organs of white mice. Am. 7. Physiol. 181, 477.

Ghristian, J. J. \& LeMunyan, C. D. (1958) Adverse effects of crowding on lactation and reproduction of mice and two generations of their progeny. Endocrinology, 63, 517.

Christian, J. J., Lloyd, J. A. \& Davis, D. E. (1965) The role of the endocrines in the self regulation of mammalian populations. In: Recent Progress in Hormone Research, 21. Ed. G. Pincus. Academic Press, New York.

Helmreich, R. L. (1960) Regulation of reproductive rate by intra-uterine mortality in the deer mouse. Science, $132,417$.

Hopkins, T. F. \& Pincus, G. (1965) Effects of rat hypothalamic and cerebral tissue on PMS-induced ovulation. Endocrinology, 76, 1177.

Mody, J. K. \& Christian, J. J. (1961) Adrenals and reproductive organs of female mice kept singly, grouped, or grouped with a vasectomized male. f. Endocr. 24, 1.

O'STEEN, W. K. (1964) Suppression of luteinization with serotonin in gonadotrophin-treated immature rat. Anat. Rec. 148, 318.

Wilson, E. D., Runner, M. N. \& Zarrow, M. X. (1963) Effect of hypothyroidism, diet and litter size on superovulation in the mouse and rat. 7. Reprod. Fert. 5, 223.

ZARROW, M. X. \& BROWN-Grant, K. (1964) Inhibition of ovulation in the gonadotrophin-treated immature rat by chlorpromizine. F. Endocr. 30, 87.

Zarrow, M. X., Caldwell, A. L., Hafez, E. S. E. \& Pincus, G. (1958) Superovulation in the immature rat as a possible assay for LH and HCG. Endocrinology, 63, 748.

ZARRow, M. X. \& HurLbUt, E. C. (1967) Inhibition and facilitation of PMS-induced ovulation in the immature rat following treatment with progesterone. Endocrinology, 80, 735.

ZARRow, M. X. \& QUINN, D. L. (1963) Superovulation in the immature rat following treatment with PMS alone and inhibition of PMS-induced ovulation. F. Endocr. 26, 181. 